\title{
Open Education Resources and Mobile Technology to Narrow the Learning Divide ${ }^{1}$
}

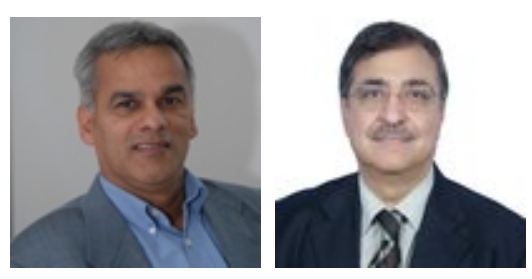

Mohamed Ally ${ }^{1}$ and Mohammed Samaka ${ }^{2}$

${ }^{1}$ Athabasca University, Canada, ${ }^{2}$ Qatar University, Qatar

\section{Abstract}

As the world becomes more digitized, there will be an increasing need to make available learning resources in electronic format for access by information and communication technologies. The question education will face is whether these learning resources will be available for learners to access at no cost or affordable cost so that there will be equity in access by anyone regardless of location, status, or background. With initiatives such as the Millennium Development Goals and Education For All by the United Nations (United Nations, 2011) learning materials must be available as open education resources to achieve the goals. Currently, most learning materials are available at a cost for people to purchase to learn, or they have to travel to a specific location (school or library) to access learning materials. In some parts of the world, especially in developing countries, these costs are prohibitive, preventing learners from achieving a basic level of education so that they can be productive in society and improve their quality of life (Bhavnani et al., 2008). Some would say that people in remote locations and developing countries do not have computers to access learning materials. It is true that many do not have desktop or laptop computers to access learning materials, but they have mobile devices and are now obtaining tablets with wireless capability to allow them to access learning materials from anywhere and at any time. These countries are bypassing the wired desktop stage and moving directly to wireless mobile technology (Bhavnani et al., 2008). Storing open education resources (OER) in electronic repositories will allow learners to access the resources using mobile technology. With mobile technologies, learners can complete coursework and assessments from anywhere and send their work to their tutors electronically and receive feedback (GSMA, 2011).

${ }^{1}$ This publication was made possible by NPRP Grant \# 4 - 125 - 5 - 016 from the Qatar National Research Fund (a member of Qatar Foundation). The statements made herein are solely the responsibility of the authors. 
Keywords : Open education resources; mobile technology; reusable learning objects

\section{Introduction}

With an estimated 5.3 billion mobile cellular subscriptions worldwide (ITU, 2010), we are starting to see the disappearance of the digital hardware divide; however, we now have the learning divide where the gap is between learners who have access to learning materials and learners who do not have access to learning materials because they cannot afford to travel to other locations or pay for the high cost of textbooks and other learning materials. Educators need to narrow the learning divide gap by making learning materials available as OER which will bring down the cost of learning materials. The combination of mobile technology and OER will enable institutions, organizations, and companies to narrow the learning divide so that there can be Education For All. Everyone has a right to obtain at least a basic education level so that they can contribute to society and improve their quality of life; however, education is more than providing access to content. It should facilitate the formation of learning communities for learners to interact (Cleveland-Innes et al., 2012; Cross, 2008; Havelock, 2004; J eng et al. (2010), share experience, and learn from each other. Use of mobile technology allows learners to access OER and at the same time participate in learning communities. The OER initiatives and Web 2.0, which supports high levels of social interaction, are moving education into the Learning 2.0 era where content and social interaction will go together to provide global education (Brown \&Adler, 2008).

A major issue in education around the world today is the shortage of teachers and physical schools for students to go to learn. The United Nations estimates that 8 million teachers will be required by 2015 (The Guardian, 2011; West, 2012). It is impossible to train 8 million teachers by 2015. Rather than training more teachers there should be a transformation of education where fewer teachers are required and learning materials are delivered to learners in their communities rather than taking the learners to the physical schools. Governments cannot continue to fund the current education system, which was designed many years ago. The current system is geared to those learners who have the resources to go to a physical school to learn. The education system must be changed so that it is flexible to meet the needs of all students regardless of location, economic status, social status, or gender. Learning materials should be delivered to students using mobile technology rather than denying students an education because of any shortage of teachers and physical classrooms. The country of India alone reported a shortage of 460,000 physical classrooms to educate students (The Economic Times, 2011). Resources are required to build the classrooms and more resources are required to maintain the classrooms. In addition, the students have to obtain the financial resources to travel to the physical classrooms to get an education. Many students in developing countries and in remote locations cannot afford to travel long distances to learn and governments cannot afford to build and maintain physical schools. The use of 
mobile technology to deliver OER will provide equal opportunity for everyone to learn by allowing access from anywhere and at any time.

\section{Making the Transition for Education For All with OER and Mobile Learning}

Citizens in developing countries do not have desktop computers to access information and learning materials; however, they have mobile devices. Mobile phone subscription is rapidly increasing in developing countries (The World Bank, 2012). While the mobile devices are becoming affordable, the cost of connecting to the Internet is still very high in some countries. This is a major barrier to education. Some countries (e.g., Finland) are realizing that giving citizens affordable or free access is a competitive advantage since citizens can access up to date information and connect to the world to become global citizens. Also, easy-to-mirror repositories, which make it possible to access resources with mobile devices without broadband connections, will facilitate the delivery of OER in remote areas with limited connectivity (OECD, 2007). With the rapid development of cloud computing, there will be learning in the cloud where OER and access to learner support will exist everywhere and anytime where cloud applications will facilitate sharing, networking, communication, and the production and publishing of OER (Kop \& Carroll, 2011; Wheeler \& Waggener, 2009) .

There are initiatives around the world to develop affordable mobile technology so that every citizen can own or have access to a computing device. Placing a mobile device in learners' hands will allow them to access learning materials and empower them to learn. For example, South Korea announced an initiative to digitize the K-12 curriculum by 2015 for access on tablet computers (Mims, 2011). This will allow learners of any age to use a tablet to access learning materials to continue their education as they need the knowledge and skills. Countries such as Thailand are planning to give one computing device to each child (Bangkok Post, 2011).

It is a simple task giving mobile technology to learners compared to the task of designing and delivering affordable learning materials for access with mobile technology. Based on personal experience, many innovative education initiatives that implement technology-based learning fail not because of the technology, but because of a shortage of quality learning materials and buy-in from teachers. For some developing countries in some regions that acquired computing technology for learners, the technology is not being used or utilized to the maximum because of the lack of affordable learning materials, the lack of motivation of teachers, or the lack of information and communication technology skills of teachers using the devices (Corbeil \&Valdés-Corbeil, 2007).

Another issue that educators have to deal with is that many mobile applications are developed for business and entertainment rather than education. Hence, educators have 
to adapt the education system to fit the technology. For example, mobile technologies developed for business use are more textbased since they are developed for email, texting, and accessing information. Quality learning that caters for different learning preferences and the upcoming generations of students requires mobile technologies with multimedia capabilities and the ability to deliver content to meet individual learner's needs and for learning to be interactive. Educators need to provide input to both hardware and software companies to develop appropriate mobile technologies that are multi-purpose to meet the needs of education and the other sectors of society. There should be multi-purpose mobile technology for education, business, entertainment, and information access.

There are many benefits of accessing OER using mobile technology. Learners are given the flexibility of accessing the OER from anywhere and at any time and learners can learn in their own context (Ally, 2009). In traditional face-to-face instruction, learners have to go to a specific location at a specified time to learn. This can be inconvenient, especially for those who live in remote locations. With mobile learning the learning can be more learner-centered since students are the ones who have control of their learning. Also, with the communication capabilities of mobile technology, students can interact with each other anytime and they can access the tutor from anywhere.

A major challenge for delivery of OER on mobile technology globally is that most currently available OER are in English, and learners in many countries do not read or speak English. However, some countries see students completing courses in English as an opportunity for them to learn or improve their English language skills. Yilmaz (2011), in a study of international students' use of OER, reported that $88 \%$ of the 27 students preferred to read or use OER in English even though only one respondent's mother tongue was English. The study reported that since OER are generally in English, students are obliged to choose English as a language of preference for learning from the OER.

\section{The Future of Education with OER and Mobile Technology}

As education moves further in the $21^{\text {st }}$ century and to meet the needs of the new generations of learners, educators need to re-think the way they design open education learning materials (Evans \& Forbes, 2012; Olcott, 2012). In a world where there is an information explosion and constant changes in content, having students completing long courses and programs may not be appropriate anymore. The learner should be the focus of the OER not the developer of the OER or the system. Educators should not develop and deliver OER to fit the current education system. If learners cannot access and benefit from the OER then it is a waste of resources developing OER (McAndrew, 2011). The current course and program structure and length of courses were developed for classroom face-to-face instruction where the information resided in the teacher's mind. The information is now recorded in electronic format and learners want access 
anytime and from anywhere rather than waiting for when a teacher is available to disseminate the information. For delivery of mobile technology, the structure and length of courses must be re-examined. Courses should be shorter and be designed in the form of modules and learning objects. Developers of open education courses must keep this in mind rather than using the same structure and length that were used for classroom face-to-face instruction.

The new generations of learners do not want to spend many months completing a course or many years completing a program as in the current education system. Hence, education programs should be developed in the form of modules, which are about four to eight hours long. Each module should consist of five to eight learning objects that are independent but are linked together. After students complete the learning objects in a module, and have their learning properly assessed, they will have successfully completed it and should be given credit for that module.

Problem-based learning can be used to promote deep learning. In problem-based learning, learners are given problems and they have to locate the information and apply that information as they solve the problem. Problem-based learning also allows learners to collaborate with each other and be active in the learning process (Hmelo-Silver et al., 2007; Rhem, 1998). If learners need help while solving a problem, they can access a coach or a tutor. The use of mobile technology for problem-based learning makes learning flexible where learners can access information from anywhere and anytime and they can communicate with experts in the field and with their tutors and peers. With mobile learning, learners can also learn in their own environment and in an environment where they can apply what they learn. They can solve problems in their own contexts rather than in contexts they are not familiar with.

Classroom face-to-face courses should not be copied and placed on the Internet as OER. Online OER courses must be designed properly to facilitate flexible delivery. It is important to train educators on how to design OER so that they are of high quality, resulting in high level learning as well as meeting the needs of learners globally. The OER should take into consideration cultural differences, different values, and different contexts of the learner. Educators need to internationalize the OER to maximize access. In a recent UNESCO report (OPAL, 2011), some barriers for implementing OER that were identified include lack of skills to create global OER and lack of OER that are culturally relevant.

It is important for learners and teachers to locate OER easily to meet their needs. Chen (2011) conducted a study on teachers' use of OER and found that two major obstacles for teachers in the use of OER are locating the OER and finding the most appropriate OER. The resources should be tagged properly so that anyone from anywhere can locate them. The interface the learner is using should have built-in intelligence to monitor learner progress and needs and to find the appropriate OER. The selection of OER for specific learners could be based on the learner's preference and context, the learner's 
level of expertise, and the language of the learner. The system should select and assemble the OER for learners.

Teachers should be trained on how to integrate OER into their existing courses and courses they are developing for mobile learning. Students are using mobile technology and social media to communicate with each other and to share information. Teachers need to be trained on how to effectively use social media in the teaching process since this is how students interact with each other and form virtual communities (Yardi, 2008). Teachers should allow students to use mobile technology to interact with each other, to access information, and to interact with experts in the field.

There are many open source learning management systems available to help teachers deliver courses over the Internet (van Rooij, 2009). For example, MIT announced an open source learning platform called MITx that will allow teachers to organize and present course material to enable students to learn at their own pace, build interactivity, complete online laboratories, participate in student-to-student communication, conduct individual assessment of any student's work, and allow students who demonstrate their mastery of subjects to earn a certificate of completion (MIT, 2011). Mobile technology with open source learning platforms and OER will provide flexible and affordable learning for all. An example of an open source learning management system for mobile learning is Mobile Moodle which allows educators to deliver and manage courses on mobile devices.

The proliferation of the Internet and social media is allowing learners to learn from each other and to access information when needed for just-in-time application. If learners have a question about a course they usually ask their peers first before they contact the teacher or tutor, especially if they need the information during non-working hours when the teacher or tutor is not available. In a study on how students access information, Saw and Todd (2007) reported that when they asked students where they begin their search for information on a topic, $84 \%$ said they use a search engine, 6\% said they email someone, while only $1 \%$ connect to the library Web site to access information. This result is not surprising since students usually search for information on the Internet when they need the information. They are the "now" generation and they want the information right away.

The information on the Internet and social media is being generated by students, researchers, and educators. The challenge for learners is to make sure they access accurate information when they use other learners' generated content. Pérez-Mateo et al. (2011) proposed quality criteria for evaluating user-generated content under the categories content, format, and process. As learners are trained and become experienced using the criteria to develop learning objects, they can develop quality OER (Moisey et al., 2006). As more and more users of the Internet generate information and learning materials, learners must check with experts in the field to make sure the learning materials are valid. One way to do this is for learners to access learning materials from accredited educational institutions, credible organizations, and experts 
in the field. The challenge for OER providers and researchers is how to make sure the open education resources are accurate for learners to obtain a valid education. Some studies on the use of OER reported that educators are concerned about the quality of OER (Badarch \& Knyazeva, 2011; Chen, 2011; Yilmaz, 2011). A major challenge for educators is the development of quality OER. But the question is how to define quality for global use and to meet global needs. This requires setting global standards for the development of OER so that the OER meet the needs of users around the world.

Keegan and Bell (2011) conducted a study where they asked students to generate videos as OER. They reported many benefits of having students generate their own content. Benefits included the following: Students became creative in the process of generating the video, they learned the content as they produced the videos, and they were able to share the videos with their colleagues. The videos were posted on YouTube with many peers and users providing excellent comments on the video. Having students generate OER has many advantages for them and their peers. As novices in the field they will use simple language, step-by-step procedures, and examples their peers will understand. At the same time, students will process the content at a high level as they generate the OER (Craik \& Lockhart, 1972; Schwier \& Misanchuk, 1993; Sternberg, 1998; Stoyanova \& Kommers, 2002).

To achieve Education For All (UNESCO, 2000) with mobile learning, there must be significant shifts in the way education is designed and delivered and in how learning outcomes are evaluated for certification. Learning materials must be designed and be accessible for everyone to access. For example, a lesson on mathematics can be developed and validated by experts at one educational organization and placed on the Internet for everyone to access rather than having millions of teachers around the world developing the same lesson. Having many teachers developing the same lesson topic is a misuse of human resources and a waste of teachers' time. Teachers should spend time tutoring students rather than duplicating the development of learning materials.

One example of an initiative that is helping to achieve the Education For All goal is the Khan Academy. As of the end of 2011, over 92 million lessons were accessed around the world (Khan Academy, 2011). If learning materials are available as OER, learners and teachers will use the learning resources as illustrated by the Khan Academy initiative. Some publishers are publishing their books as open access so that anyone can use the book for educational purposes. For example, Athabasca University Press is publishing books as open access, which is contributing to bridging the learning divide and making education available for all. Other initiatives include The Open Content Alliance (2012), which is building a permanent archive of multilingual digitized text and multimedia material that will cater for different cultures and learning styles. The University of the People (2012) is the first tuition-free online academic institution dedicated to providing global access to higher education. It is taking advantage of the Internet to reach people around the world so that they can have access to education. Courses that can be delivered on mobile devices will allow learners with mobile devices and connectivity to access the learning materials from anywhere and at any time. Also, the World Digital 
Library (2012) is a global initiative that will allow free access to information and learning materials. Libraries will be networked together to maximize the amount of information learners can access. Bonk (2010) listed a number of Web sites that provide free learning materials for students to access anywhere and anytime.

A recent initiative that will reduce the cost of obtaining a formal education is the Open Education Resources University $(\mathrm{OERu})$, which is a consortium of accredited universities around the world that is planning to offer formal courses at a significantly reduced cost, making education affordable to millions of students (Attwood, 2011). The OERu system will check students' prior knowledge and skills to see if they already have the expertise in the course they are interested in completing. If students pass the prior learning assessment, they will not have to complete the course and they can move on to the next course. The use of prior learning assessment benefits students and the education system. If students already have the knowledge and skills that will be presented in the course, why should they waste their time taking the course? The education system and students will benefit since some students will not have to take courses they already know. The OERu will play an important role in lifelong learning around the world since learners of any age can complete courses at an affordable cost. The OERu will have a major global impact if the courses are delivered on mobile devices since many citizens in developing countries do not have desktop computers but they have mobile phones and tablets. For citizens in developing countries, low-cost education and low-cost computing devices are important for them to access education.

A recent report from the Commonwealth of Learning provided suggestions for academic staff to successfully implement OER (COL, 2011). These include the following: develop skills to evaluate OER; consider publishing them; assemble, adapt, and contextualize existing OER; leverage networks and communities of practice; encourage student participation; promote OER use through publishing about OER; provide feedback about, and data on the use of, existing OER; and update knowledge of intellectual property rights, copyright, and privacy policies. Guidelines such as these are important for the successful implementation of OER; however, there should be training programs for teachers on how to develop and implement them and how to provide support to students who are completing OER courses. Educators should be made aware that OER exist and be educated on how to access them and the benefits of using them (Nikoia \& Armellinib, 2012). If educators do not see the benefits of using OER, they will not use or promote their use of OER. In a discussion forum involving 500 individuals from around the world, participants identified awareness, training, and promotion as major issues for the successful implementation of OER in education (Antoni, 2008).

\section{Conclusion}

There have been many conversations on what an OER is and how OER will benefit the world but not enough dialogue on how to implement OER to have a global impact so 
that we have Education For All. There has to be a sense of urgency to prove to decision makers that OER will have a significant impact on education through social inclusion and justice so that everyone can achieve a basic level of education. In addition, research is needed on developing OER for lifelong learning, setting standards for developing and delivering quality OER, developing intelligent OER, and designing optimal assessment and certification of learners after they complete OER. Also, as libraries become mobile friendly and librarians continue to develop their technological skills, they will have a major role to play in the organization and delivery of OER (Krist, 2011; Singh, 2008). More work is needed to determine the changing role of librarians and how they can contribute to the successful implementation of OER.

All too many OER are being developed using the face-to-face classroom paradigm of education. If OER are to have a significant impact on education so that Education For All is possible, and the need for millions of teachers and physical classroom space is reduced, there must be a significant shift in the way education is delivered. Many learners around the world cannot afford to go to a physical location to learn because of a lack of financial resources and transportation infrastructure. Citizens of all countries must be empowered to learn by giving them the technology to access learning materials from their local communities. Educators must design OER for access at no cost or low cost so that learners can readily access the OER. Future learning will be ubiquitous where learners will be mobile and will learn anywhere and anytime (McGreal, 2010). Mobile learning with open educational resources is the future of education (Young, 2009). As we move into the OER era we need to transform education with the goal of Education For All. If educators do not take the opportunity to implement OER, future learners may bypass the education system and access OER without registering at an educational institution. The learners can then demonstrate to potential employers that they have the expertise for employment and the potential employers will certify and hire the learners. This could be one potential model of education in the future that will change the way education is delivered. For many people around the world the cost of education is too high, the education system is too rigid and inflexible, and the system is resistant to change. There has to be a transformation of education before there is an educational revolution by the current and upcoming generations of learners. This is the time to transform education because learners have the technology in their pockets and are able to access OER anywhere and anytime. 


\section{References}

Ally, M. (2009). Mobile learning: Transforming the delivery of education and training. Athabasca, Alberta : Athabasca University Press. Retrieved from http:// www.aupress.ca/index.php/books/ 120155

Antoni, S. (2008). Open educational resources: The way forward (UNESCO report). Paris : UNESCO.

Attwood, R. (2011). 'OER university' to cut cost of degree. Times Higher Education, 10 February 2011.

Badarch, D., \& Knyazeva, S. (2011, October). Open educational resources: Evidence from non-English speaking countries. Paper presented at the 24th ICDE World Conference on Open and Distance Learning, Bali, Indonesia.

Bhavnani, A., Chiu, R. W., J anakiram, S., \& Silarszky, P. (2008). The role of mobile phones in sustainable rural poverty reduction (World Development Report 2008). Retrieved from http://www.igov.org/images/articles/7576/The Role of Mobile_Phones in Sustainable Rural_Poverty_Reduction_June 2008.pdf

Bonk, C. J . (2010). For openers: How technology is changing school. Educational Leadership, 67(7), 60-65.

Brown, J . S., \& Adler, R. P. (2008). Open education, the long tail, and Learning 2.0. Educause Review, J anuary/ February 2008, 17-32.

Chen, Q. (2011, October). OER utilization and needs analysis for distance education teachers in China: A survey report. Paper presented at the 24th ICDE World Conference on Open and Distance Learning, Bali, Indonesia.

Cleveland-Innes, M., Ally, M., Wark, N., \& Fung, T. (2012, October). Emotional presence and mobile learning: Learner-driven responses in a wireless world. Paper presented at the 7th EDEN Workshop, Leuven, Belgium.

Commonwealth of Learning (COL). (2011). Guidelines for open educational resources (OER) in higher education. Retrieved from http:// www.col.org/ resources/publications/Pages/detail.aspx?PID=364

Corbeil, J . R., \&Valdés-Corbeil, M. E. (2007). Are you ready for mobile learning? Your students are! Full paper proceedings and presentation at the 5th Hawaii International Conference on Education, Honolulu.

Craik, F. I. M., \& Lockhart, R. S. (1972). Levels of processing: A framework for memory research. J ournal of Verbal Learning and Verbal Behavior, 11, 671- 684. 
Cross, K. P. (1998). Why learning communities? Why now? About Campus, July August 1998, 4-11.

Evans, R., \& Forbes, L. (2012). Mentoring the 'net generation': Faculty perspectives in health education. College Student J ournal, J une 2012, 397-404.

Global teacher shortage threatens progress on education. (2011, October 7). The Guardian.

GSMA. (2011). The mobile proposition for education. Retrieved from http:// www.gsmaembeddedmobile.com/upload/resources/files/MobileProp_R eport 08-12-11 Interactive.pdf

Havelock, B. (2004). Online community and professional learning in education: Research-based keys to sustainability. Association for the Advancement of Computing In Education, 12(1), 56-84.

Hmelo-Silver, C. E., Duncan, R. G., \& Chinn, C. A. (2007). Scaffolding and achievement in problem-based and inquiry learning. Educational Psychologist, 42(2), 99107.

India faces a shortage of over 4.6 lakh classrooms. (2011, December). The Economic Times.

ITU (2010). The world in 2010: Facts and figures. Retrieved from from http:// www.itu.int/ITU-D/ict/material/FactsFigures2010.pdf

J eng, Y. -L., Wu, T. -T., Huang, Y. -M., Tan, Q., \& Yang, S. J . H. (2010). The add-on impact of mobile applications in learning strategies: A review study. Educational Technology \& Society, 13 (3), 3- 11.

Keegan, H., \& Bell, F. (2011). YouTube as a repository: The creative practice of students as producers of open educational resources. Retrieved from http:// www.eurodl.org/ ?p=current\&article=456.

Khan Academy. (2011). Retrieved from http:// www.khanacademy.org/

Kop, R., \& Carroll, F. (2011). Cloud computing and creativity: Learning on a massive open online course. Retrieved from http:// www.eurodl.org/ ?p=special\&sp=articles\&inum=2\&article=457

Krist, K. G. (2011). Natural partners: Libraries and open source initiatives. Retrieved from http:// www.infosherpas.com/ ojs/index.php/openandlibraries/article/viewFile $\angle 40 / 60$ 
McAndrew, P. (2011). Inspiring creativity in organizations, teachers and learners through open educational resources. Retrieved from http:// www.eurodl.org/ materials/ special/2011/McAndrew.pdf

McGreal, R. (2010). Mobile devices and the future of free education 2010. Retrieved from http:/ / wikieducator.org/images/ e/ ef/SJ_Rory_MoGreal.pdf

Mims, C. (2011). Samsung windfall: All of South Korea's textbooks to go digital by 2015. Technology Review. http:// www.technologyreview.com/blog/ mimssbits/26960/

MIT (2011). MIT launches online learning initiative. MIT News. Retrieved from http:// web.mit.edu/ newsoffice/ 2011/ mitx-education-initiative-1219.html

Moisey, S., Ally, M., \&Spencer, B. (2006). Factors affecting the development and use of learning objects. American J ournal of Distance Education, 20(3), 143-161.

Nikoia, S., \&Armellinib, A. (2012). The OER mix in higher education: Purpose, process, product, and policy. Distance Education, 33(2), 165-184.

OECD (2007). Giving knowledge for free: The emergence of open educational resources. Retrieved from http:// www.oecd.org/document/41/0,3746,en_2649 $3584558138659497 \quad 1$ 1 1 1 1,00.html

Olcott, D. (2012). OER perspectives: Emerging issues for universities. Distance Education, 33(2), 283-290

OPAL. (2011). Beyond OER: Shifting focus from resources to practices the OPAL Report 2011. Open Educational Quality Initiative. Retrieved from http:// portal.unesco.org/ci/en/ev.php-

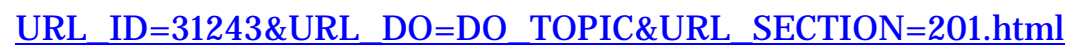

Open Content Alliance. (2012). Building a digital archive of global content for universal access. Retrieved from http:// www.opencontentalliance.org

Pérez-Mateo, M., Maina, M. F., Guitert, M., \& Romero, M. (2011). Learner generated content: Quality criteria in online collaborative learning. Retrieved from http:// www.eurodl.org/ ?p=current\&article $=459$

Rhem, J . (1998). Problem-based learning: An introduction. The National Teaching and Learning Forum, 8, (1), 1-4.

Saw, G., \& Todd, H. (2007, August). Library 3.0: Where art our skills? World library and Information: 73 ${ }^{\text {rd }}$ IFLA Conference and Council, Durban, SA. 
Schwier, R. A., \&Misanchuk, E. 1993. Interactive multimedia instruction. Englewood Cliffs, NJ : Educational Technology Publications.

Singh, N. (2008). The librarian as essential key to connecting open educational resources and information literacy in the academic world. Open and Libraries Class J ournal, 1(1), 1-9.

Sternberg, R. J . 1998. Meta-cognition, abilities, and developing expertise: What makes an expert student? Instructional Science, 26(1-2), 127- 140.

Stoyanova, N., \& Kommers, P. (2002). Concept mapping as a medium of shared cognition in computer-supported collaborative problem-solving. J ournal of Interactive Learning Research, 13(1,2), 111- 133.

Thailand's one tablet per child policy. (2011, September). Bangkok Post.

The World Bank. (2012). Mobile phone access reaches three quarters of planet's population. Retrieved from http:// www.worldbank.org/en/news/2012/07/17/ mobile-phone-accessreaches-three-quarters-planets-population

UNESCO (2000). Dakar Framework for Action, Education For All: Meeting our collective commitments. Retrieved from http:// unesdoc.unesco.org/images/ 0012/001211/121147e.pdf

United Nations. (2011). The Millennium Development Goals report 2011. Retrieved from http:// www.un.org/ millenniumgoals/reports.shtml

University of the People. (2012). UoPeople: Tuition-free online university. Retrieved from http://www.uopeople.org

van Rooij, S. W. (2009). Adopting open-source software applications in U.S. higher education: A cross-disciplinary review of the literature. Review of Educational Research, 79 (2), 682- 701.

Wheeler, B., \&Waggener, S. (2009). Shaping the promise of cloud computing for higher education. Educause Review, November/ December 2009, 52-66.

West, M. (2012). Mobilelearning for teachers: Global themes. UNESCO Working Paper Series on Mobile Learning. Retrieved from http:// www.unesco.org/new/ en/ unesco/themes/icts/m4ed .

World Digital Library. (2012). World Digital Library. Retrieved from http://www.wdl.org/en/

Yardi, S. (2008). "Whispers in the classroom." Digital youth, innovation, and the unexpected. In T. McPherson (Ed.), TheJ ohn D. and Catherine T. MacArthur 
Foundation Series on digital media and learning (pp. 143- 164). Cambridge, MA: The MIT Press. doi: 10.1162/ dmal.9780262633598.143

Yilmaz, M. (2011, October). Open educational resources: Students' perspectives in an international learning environment. Paper presented at the 24th ICDE World Conference on Open and Distance Learning, Bali, Indonesia.

Young, B. (2009). Access to education in Africa: Mobile learning and open educational resources. Access to Knowledge: A Course J ournal, 1(1), 1-7.

\section{Athabasca University $\mathbf{a}$}

(2) $\stackrel{0}{\mathrm{IV}}$ 